\title{
Sino-Foreign Cooperation in Education: An Effective Approach for the Transformation and Development of Local Universities
}

\section{Fu Qiang}

International College of Shenyang University, Liaoning, Shenyang, 110044

\begin{abstract}
Keywords: English teaching; Sino-foreign cooperation in education; transformation
\end{abstract}
\begin{abstract}
English teaching is not only in the key position, but the effect of innovation directly affects the success of the Chinese and foreign cooperative running programs. Sino-foreign cooperation in educational project belongs to the new model of school running, which puts forward higher demands for the English teaching in the transition and development of local universities. Under this background, only focusing on the teaching problems in students' learning motivation is not enough, weak teaching strength, teaching materials localization and other aspects of teaching have become major problems. Therefore, it is of great significance to strengthen the teaching status analysis and propose targeted optimization strategies for English teaching [1].
\end{abstract}

Sino-foreign cooperation in running schools is a bilateral educational institution, which aims at the education and teaching activities held in China under the policy of related school running regulations and implementation methods. With the increasing demand for talent in China, the teaching model has been widely concerned and recognized by all walks of life. Although the undergraduate English teaching in the project has made a great progress, it still has a large room for improvement and is worth studying.

\section{Significance and achievement of Chinese and foreign cooperative school running projects}

First of all, we should draw on the teaching experience of foreign advanced countries, actively absorb the resources of high quality education, and improve the quality and level of running a university in China. With the help of higher and vocational education, the introduction of foreign educational resources in China's Sino foreign cooperation in running schools has a clear explanation in the Chinese foreign cooperation in running schools Ordinance (2003). The internationalization of education development today, the correct understanding of Sino foreign cooperative education project is the key, combined with TAEE, absorbing foreign advanced experience in teaching, such as teaching methods, advanced technology, teachers, curriculum resources for colleges, higher occupation education in our country, both at the school level, scale grade, quality is more good than harm [2].

Secondly, in order to meet the needs of economic and social development, more international talents can be trained in the society. With the rapid development of economy, the demand for comprehensive talents in various fields has been expanding. Training international technology and management talents has become an important task of higher education. Through international cooperation, the gap between domestic higher vocational education and national education can be shortened. In addition, in the practice of Chinese and foreign cooperation in running schools, a large number of international and high-quality talents have been trained, and the sustainable development of the economy and society plays an important role.

First of all, it meets the needs of the labor market for talents and strengthens the category of talent training. In the Sino foreign cooperative education project, teaching a part by professional accomplishment, the teacher occupation skills at home, the other part of the course teaching by teachers, bilingual teaching for students is not only a challenge is an exercise of students' English ability, professional skills and literacy, the future employment competitiveness of great help [3].

Secondly, the professional development and curriculum system are optimized. Through Chinese and foreign cooperation, students can come into contact with advanced teaching methods, ideas and 
teachers in foreign countries, so as to achieve the integration of western culture. Foreign teaching idea pays more attention to student dominance, and pays more attention to students' autonomous learning, active participation and practical skills training, while making up for the drawbacks of traditional teaching in China, and improving the professional curriculum system.

Finally, the teachers are strengthened to ensure the quality and quality of the course teaching. Actively introducing foreign advanced teachers, management evaluation and management mode can help teachers achieve teaching improvement, and improve teachers' professional quality and professional skills. The communication and communication between Chinese and foreign teachers not only achieves experience sharing, but also promotes the systematic and standardized development of teaching management, so as to ensure the overall teaching level and quality improvement.

\section{The present situation of English teaching in Chinese and foreign cooperative schools}

There are limited basic knowledge of English for local undergraduate universities in Sino foreign cooperation in running schools, and individual differences in English acceptance ability are large. Most of the scores belong to the middle and lower scores of the admission line, and the theoretical knowledge and practical ability are relatively lack, and they do not have the good habit of self-study. Only $30 \%$ of the students who choose to study abroad through investigation and development are generally superior families, but their self-control is poor. They rely on teachers to help them allocate their time and plan for the future.

In Sino foreign cooperative education programs, English teachers mainly include domestic teachers, foreign teachers, and foreign teachers, which help students build good learning atmosphere and help students' English language sense correction, cultural exchange, and so on, and students' interest in learning. But the disadvantages lie in the following aspects. Firstly, the resources of foreign teachers are relatively few, and the introduction of foreign teachers is lack of supervision. The procedures are not good enough, and the introduction mechanism is not standardized, which leads to the lack of unity of professional skills and professional accomplishment of foreign teachers. Secondly, the foreign education is unstable and fluidity, and it is not conducive to the students' learning progress, the connection of teaching tasks, and the transition of the teaching situation. In addition, the foreign language teaching level is limited, and there are obstacles to communicate with Chinese teachers and students. It can not fully grasp students' individual differences and needs for English teaching, which leads to teaching objectives deviating from reality, and failing to achieve teaching needs and teaching students in accordance with their aptitude can not guarantee teaching efficiency and quality. Finally, there is a lack of communication between Chinese and Regional Teachers in different cultures and different teaching concepts. Therefore, conflicts between teachers and students can not be avoided, so it is difficult to ensure teaching effectiveness [4].

First of all, the localization of the teaching materials is serious. Teaching material is an important medium to guarantee the effect of teaching, and it is also an important carrier for students to absorb knowledge. The teaching material resources, which are in line with the Chinese and foreign cooperative school programs, can provide students with more targeted examples of Chinese and foreign cultural knowledge. But in fact, the teaching materials used by local undergraduate colleges and universities are still original textbooks, which are awkward in the introduction of foreign teaching material resources, the lag of traditional teaching materials and the difficulty of compiling textbooks. Partners to provide materials, far beyond the actual acceptance of students ability, make the students not the first reaction of foreign teachers teaching information, and it is difficult to express and communicate with foreign teachers in normal, their thoughts and feelings can not express, also need to solve the problems in current English teaching.

Secondly, in the teaching method, the information teaching is not realized. A single teaching method not only reduces students' interest in learning, but also does not fully explain the contents of teaching. It is not conducive to students' English listening, speaking, reading and writing, as well as the comprehensive ability of personalization and creativity. 
The new teaching mode of Chinese and foreign cooperative education needs to be constantly optimized in practice, and the management system should be perfected actively, including evaluation and assessment system, etc. Through the perfect management system and examination system, the sustainable development of education is ensured. In fact, most of the colleges and universities do not attach importance to the construction of management system and assessment system, and the practice is formalized, and the effect of implementation is not ideal. At the same time, the construction of management methods and management team has not been strengthened. The teaching management and the students' work managers do not accept the professional management training, and the effectiveness of the management and assessment methods can not be guaranteed. In the process of actual management and assessment, there is often a conflict of opinions between Chinese and foreign employees [5].

\section{Perfect countermeasures for English teaching in the transition}

The project of Sino foreign cooperative education in local universities is mainly aimed at training high-quality talents with international vision and applied talents with comprehensive theories and practice. In order to ensure the standardization and normalization of curriculum implementation, to achieve the pertinence of teaching methods and the rigor of evaluation system, we first need the uniform quality of student resources, which is particularly critical for this policy. Strictly enact the training requirements of Chinese and foreign cooperative education projects, and make enrolment plans. In order to ensure the smooth expansion of English Teaching in Chinese and foreign cooperative schools, the grades of students' English scores are specified. But in fact, it is not feasible to improve enrollment threshold and enhance the quality of students. After entering school, students need to take graded and stratified teaching methods to enhance students' English achievement. Except should pay attention to the ideological and moral education of students, help them establish correct views, and promote the all-round development of students.

In order to ensure the stable development of the cooperative program, the professional and high level teachers are the most critical, so that the quality of English teaching is guaranteed. At present, strengthening the construction of teaching staff is also necessary for the joint efforts of schools and teachers. For example, the teachers' structure in the Chinese and foreign cooperative school programs, such as the Shenyang University, mainly includes three parts of the Chinese teachers, foreign teachers and Chinese foreign teachers. Teachers should have rich experience, professional knowledge and English level. The development of foreign teachers' direct relation projects, and the competitiveness and reputation of the school. In order to ensure the unification of foreign teachers and avoid mobility problems, the recruitment system for foreign teachers has been strictly established, which stipulates that foreign teachers must be above undergraduate degree and qualified as teachers. The Chinese teachers and foreign teachers, are required for graduate education, and regularly or irregularly to participate in professional training, or is involved in educational institutions of learning activities, constantly updating the teaching concept, knowledge level, and then to enhance their scientific research, theory and practice level, ensure project smoothly. Regularly carry out Sino foreign teachers' exchange seminars, so that they can enjoy each other's experience, complement each other's strengths, understand students' English theory and practice level, and achieve targeted teaching.

First of all, in the teaching goal, we can carry out stratified teaching according to the students' English level. It is divided into different classes in ABC, and it is more conducive to teaching students in accordance with their aptitude through small classes. For example, we carry out Academic reading and vocabulary skills course teaching for A class, carry out Writing and, learning and other courses teaching for B class students, and carry out teaching in the "ban" class. There are also differences in the difficulty of English Teaching in different English classes.

Secondly, in the textbook to encourage self-control, such as the Shenyang University compiled "oral English Course" series, "English academic writing" series, teaching materials not only conforms to the teaching goals of Chinese foreign cooperation in running the school project, and also relates to the vocabulary and grammar is more practical, and at the same time into a large 
number of Chinese and foreign cultural background, to lay the foundation for the students have an international perspective. Besides, in addition to the content of the teaching materials, teachers should refer to the cases of foreign experts to master English skills for their domestic students and help students master English knowledge and skills. Such as AJE (American Journal experts) of English writing modifier application case, namely "The patient experienced severe pain in his right arm when lifting objects for three months" need to pay attention to language in scientific writing in the correct expression, so more accurate wording should be "For three months, the patient experienced severe pain in his right arm upon lifting an object", to help students in writing rigorous rigorous terms, to avoid the wrong use of modifiers.

In the listening course, the network teaching resources can be implemented to guide the students to carry out the listening test. At the same time, students need to pay attention to self-study and exercise. The traditional listening course not only has less time, but also the teaching method is single, and it can not meet the students' needs of learning and living in foreign countries. In this regard, independent training courses are set up in the course of course setting. The students through the network listening test system, carried out weekly listening tasks, quizzes, waiting to preliminary form, listening to students learning task level examination. In addition, the network management platform can also be used to monitor the development of students' English listening intensive practice. Students can read the original text on the line, communicate the problem line with the teachers to ensure the improvement of the listening level.

In oral English course, based on foreign teachers' testing software, autonomous learning methods and students' teaching courses outside, they can learn with the help of web based autonomous learning software, such as MYET. Gradually increase the difficulty of the assessment standard according to the learning progress, and help the students to improve their oral ability.

In reading and writing can be taken to flip the classroom teaching method, students through teamwork, mutual supervision together to complete the Internet resources courses learning, stimulate students interest in learning at the same time, let the student through cyber source, to better grasp the reading experts at home and abroad Qinshou reading and writing skills, at the same time required reading and writing input output. Together, such as "Growing evidence suggests that plasma ACE activity, the key enzyme of the RAS, may be higher in adults with several cardiovascular disorders" in "the key enzyme of RAS", and not for the modification of "activity" but "ACE", in this reading, writing should be clear grasp of language tools to avoid the influence of sentence structure, sentence meaning the overall error.

The grading system is also adopted for student assessment. The assessment standard of listening, reading ability and writing ability of students is divided into ABC level, and the excellent and qualified IELTS at all levels are different. Such as A-level standard, excellent and pass the IELTS scores were 6 points, 5.5 points, criteria: completely understand the listening test subject tedious, to clearly describe the main content, the test can read the contents of the article, write the topic articles, enrich the content and expression of the correct statement. The difficulty of the BC level assessment standard is relatively low, and it can clearly evaluate the students' learning level [6].

\section{Conclusions}

The local undergraduate students in the cooperative learning program not only finish the domestic curriculum learning, but also complete the whole English course abroad, which sets higher standards for students' English level, and also brings challenges to English teaching. In this regard, colleges and universities need to innovate in all aspects of teaching staff building, enriching teaching materials, and so on, which will enhance the competitiveness of schools, and lay a good foundation for Chinese characteristic colleges and universities.

\section{Acknowledgements}

Fund Project: the education of Liaoning province "in 13th Five-Year 2016 annual issue of" planning "local colleges transition period of development of English teaching mode innovation 
research and practice -- a Sino foreign cooperative education project as example" project approval number: JG16DB289

\section{References}

[1] Krishnan A, Chan K M, Jayaprakash J C M, et al. Measurement of performance at institutions of higher learning: the balanced score card approach [J]. International Journal of Managerial \& Financial Accounting, 2008, 1(2):199-212.

[2] Mckibbin W J. Working Papers in Trade and Development [J]. Ejournal.narotama.ac.id, 2003.

[3] Ho L K K, Chan M K. From Minimum Wage to Standard Work Hour: HKSAR Labour Politics in Regime Change. [J]. Journal of Current Chinese Affairs, 2013, 42(3):55-86.

[4] Walt S M. The End of the American Era [J]. National Interest, 2011.

[5] Bercovitz J, Jap S D, Nickerson J A. The Antecedents and Performance Implications of Cooperative Exchange Norms [J]. Organization Science, 2006, 17(6):724-740.

[6] Wang Z. Approaches to Promote the Development of Jiangsu Development Zones [J]. Journal of Suzhou University of Science \& Technology, 2012. 